\title{
Kendali Robot Beroda Otonom dengan Invers Kinematics
}

\section{Autonomous Wheeled Robot Control with Inverse Kinematics}

\author{
MICHAEL JULYUS CHRISTOPHER MANULLANG ${ }^{1}$, MEDRIA KUSUMA DEWI \\ HARDHIENATA $^{1}$, KARLISA PRIANDANA $^{1 *}$
}

\begin{abstract}
Abstrak
Penelitian ini dilakukan untuk mengembangkan robot otonom yang dikendalikan dengan pendekatan matematika inverse kinematics. Robot yang digunakan pada penelitian ini adalah robot beroda nonholonomic differential drive. Metode penelitian yang digunakan terdiri atas empat tahapan, yaitu: penentuan parameter robot beroda, pengembangan kontrol inverse kinematics, pembuatan data lintasan (trajectory) berupa garis lurus, dan pengujian sistem kendali. Pada pengujian, data trajectory yang dibangkitkan dibandingkan dengan pengukuran berdasarkan observasi di lapangan. Pengukuran data gerakan robot di lapangan dilakukan dengan dua alat, yaitu dengan global positioning system (GPS) yang terpasang pada robot dan GPS smartphone. Hasil pengujian menunjukkan bahwa robot beroda dapat dikendalikan dengan inverse kinematics dengan rata-rata nilai galat sebesar 0.9 meter.
\end{abstract}

Kata Kunci: inverse kinematics, kendali, otonom, robot beroda.

\begin{abstract}
This research aims to develop an autonomous robot that is controlled with a mathematical approach, inverse kinematics. The robot used in this research is a non-holonomic differential drive wheeled robot. The research method consists of four stages, namely: determination of the wheeled robot parameters, development of inverse kinematics control, generation of straight trajectory data, and control system testing. In testing, the generated trajectory data is compared with measurements based on observations in the field. The measurements is done by two equipment, namely the global positioning system (GPS) installed on the robot and the smartphone's GPS. The test results show that the wheeled robot can be controlled with inverse kinematics with an average error value of 0.9 meters.
\end{abstract}

Keywords: autonomous, inverse kinematics, control, wheeled robot

\section{PENDAHULUAN}

Robot beroda adalah robot yang dapat bergerak dan berpindah posisi menggunakan roda bermotor. Penelitian ini menggunakan jenis robot beroda karena secara luas dapat digunakan pada berbagai tugas otonom di bidang datar, misalnya untuk pengelolaan bencana tanah longsor (Liu dan Nejat 2013). Robot beroda yang digunakan yaitu robot beroda nonholonomic, di mana robot jenis ini tidak dapat bergerak ke segala arah, melainkan bergantung pada jalur yang dapat dicapainya (Laumond et al. 1998).

Sejak penemuannya, robot beroda telah dikembangkan dengan menggunakan berbagai sistem kontrol, baik pendekatan mekanik (Naveed dan Khan 2017) maupun matematika (Gu et al. 2017). Namun, hingga kini lingkungan robot yang kompleks dan non-linear tetap menjadi masalah utama. Metode kontrol konvensional, seperti proportional-integral-derivative (PID) dan back-stepping controller (Thao et al. 2010), tidak dapat memecahkan masalah ini karena

\footnotetext{
1 Departemen Ilmu Komputer, Fakultas Matematika dan Ilmu Pengetahuan Alam, Institut Pertanian Bogor, Bogor 16680.

* Penulis Korespondensi: Surel: karlisa@apps.ipb.ac.id
} 
keterbatasannya dalam beradaptasi dengan karakteristik lingkungan yang berubah (Kusumoputro et al. 2016). Sistem kontrol adaptif dengan pendekatan matematika dapat menjadi solusi untuk tantangan ini, meskipun diperlukan penyesuaian pada saat diterapkan di dunia nyata (Almurib et al. 2011).

Penelitian ini menggunakan robot beroda dengan teknologi differential drive yang merupakan suatu teknik pergerakan robot dengan memanfaatkan perbedaan kecepatan dua roda. Sistem kendali yang diteliti adalah inverse kinematics yang merupakan sistem kendali berbasis pendekatan matematika. Inverse kinematics ini merupakan kebalikan dari pendekatan kinematika (forward kinematics) untuk memperoleh parameter berupa kecepatan masingmasing roda pada robot. Kecepatan roda diturunkan dari kecepatan robot pada koordinat global yang diperlukan untuk mencapai posisi akhir yang diinginkan. Sebelumnya, inverse kinematics sudah pernah digunakan untuk robot berkaki enam oleh Priandana et al. (2017). Akan tetapi, penelitian tersebut terbatas pada analisis akurasi waktu dan belum membahas akurasi perpindahan posisi robot. Selain itu, robot berkaki juga memiliki kelemahan yaitu lebih kompleks dikendalikan karena memiliki jumlah servo yang lebih banyak dibanding robot beroda. Sebelumnya, inverse kinematics juga sudah pernah digunakan oleh Maulana et al. (2014) pada robot beroda differential drive. Robot tersebut memiliki 4 roda (2 roda bermotor di bagian belakang, dan 2 roda bantu di bagian depan) dan inverse kinematics diimplementasikan untuk melacak jalur menggunakan sensor yang ada pada robot.

Penelitian ini dilakukan untuk mengendalikan robot beroda dengan pendekatan inverse kinematics serta menganalisis hasil pengendaliannya dari segi akurasi perubahan posisi robot. Pada penelitian ini, robot yang digunakan memiliki 3 roda (2 roda bermotor di bagian depan, dan 1 roda bantu di bagian belakang). Inverse kinematics diimplementasikan untuk lintasan buatan yang digunakan untuk menentukan arah pergerakan robot sehingga robot tersebut dapat berjalan secara otonom. Batasan dari penelitian ini adalah (a) fokus penelitian adalah penerapan algoritme inverse kinematics untuk mengendalikan robot beroda dengan parameter sesuai dengan robot yang digunakan, (b) lintasan (trajectory) yang dianalisis adalah trajectory garis lurus. Dengan kata lain, robot bergerak lurus dan tidak berbelok, dan (c) kecepatan motor yang dihasilkan oleh algoritme inverse kinematics tidak melebihi kecepatan maksimum motor yang digunakan, yaitu 50 rotasi per menit (RPM) atau $0.172 \mathrm{~m} / \mathrm{s}$.

\section{METODE}

\section{Kinematika Robot Beroda Differential Drive}

Pada robot beroda, persamaan kinematika (forward kinematics) mendefinisikan beberapa bagian dari pergerakan robot, di antaranya $\dot{x}, \dot{y}$, dan $\dot{\theta}$. Resultan antara $\dot{x}, \dot{y}$ adalah $v(t)$. Vektor pergerakan robot beroda ditunjukkan pada Gambar 1 dan 2 (Siegwart dan Nourbakhsh 2004, dengan modifikasi). Peubah $v$ merepresentasikan kecepatan linear, dan $\omega$ merepresentasikan kecepatan sudut robot. Persamaan untuk postur robot dinyatakan dalam bentuk seperti pada persamaan (1).

$$
\xi_{I}=\left[\begin{array}{l}
x \\
y \\
\theta
\end{array}\right],
$$

Posisi $P$ (pusat robot) pada koordinat global $(G)$ dinyatakan dalam koordinat $(x, y)$ dan perbedaan sudut antara koordinat global dengan koordinat robot $(R)$ dinotasikan sebagai $\theta$. Sementara itu, kecepatan robot beroda pada koordinat global dapat dinyatakan dalam bentuk seperti pada persamaan (2). 


$$
\dot{\xi}_{I}=\left[\begin{array}{c}
\dot{x} \\
\dot{y} \\
\dot{\theta}
\end{array}\right],
$$

Peubah $\dot{x}$ dan $\dot{y}$ yang merupakan kecepatan robot pada sumbu $x$ global $\left(X_{G}\right)$ dan $y$ global $\left(Y_{G}\right)$, serta $\dot{\theta}$ yang merupakan kecepatan sudut robot.

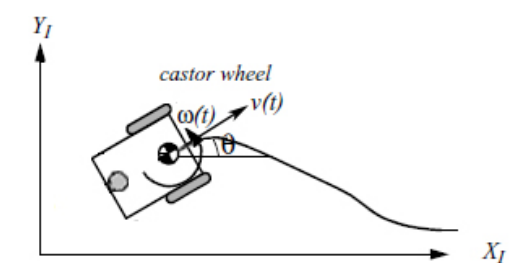

Gambar 1 Vektor pergerakan robot beroda.

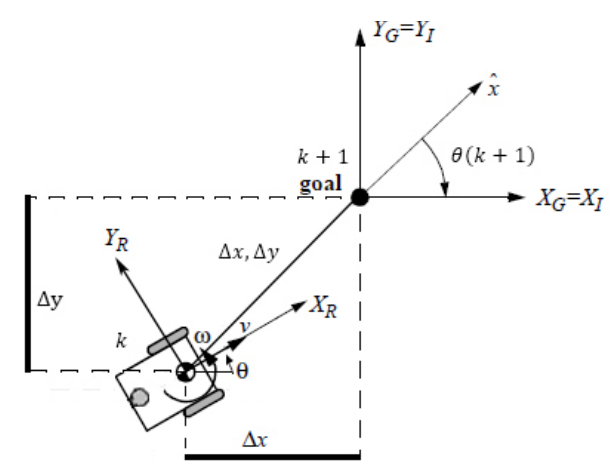

Gambar 2 Kinematika robot beroda dan lingkungannya dengan target tujuan.

Untuk mendeskripsikan gerakan robot dalam hal gerakan komponen gerakan di sepanjang kerangka referensi koordinat global $\left(X_{G}, Y_{G}\right)$ untuk bergerak di sepanjang kerangka referensi koordinat lokal robot $\left(X_{R}, Y_{R}\right)$ perlu dipetakan. Pemetaan ini dilakukan menggunakan matriks rotasi ortogonal $(R(\theta))$ seperti pada persamaan (3).

$$
R(\theta)=\left[\begin{array}{ccc}
\cos (\theta) & \sin (\theta) & 0 \\
-\sin (\theta) & \cos (\theta) & 0 \\
0 & 0 & 1
\end{array}\right] .
$$

Untuk mendapatkan kecepatan robot pada koordinat lokal robot $\left(\dot{\xi}_{R}\right)$ dari kecepatan robot pada koordinat global $\left(\dot{\xi}_{I}\right)$, persamaan (4) digunakan.

$$
\dot{\xi}_{R}=\mathrm{R}(\theta) \dot{\xi}_{I}
$$

Siegwart dan Nourbakhsh (2004) mendefinisikan dua asumsi pada roda robot yang digunakan untuk menurunkan persamaan kinematika dan inverse kinematics. Gambar 3 menunjukkan sebuah roda pada titik $A$ yang terhubung dengan pusat (origin) robot $P$. Untuk satu roda, berlaku dua asumsi yang bergantung pada jenis roda yang digunakan. Untuk jenis roda standar tetap, kedua asumsi ini dinyatakan pada persamaan (5) dan (6).

Rolling constraint (roda tidak slip)

$$
[\sin (\alpha+\beta) \quad-\cos (\alpha+\beta) \quad(-l) \cos \beta] R(\theta) \dot{\xi}_{I}-r \dot{\varphi}=0 .
$$

No-sliding constraint (roda tidak lepas dari sumbunya)

$$
[\cos (\alpha+\beta) \quad \sin (\alpha+\beta) \quad l \sin \beta] R(\theta) \dot{\xi}_{I}=0,
$$

Peubah $\alpha$ adalah posisi (sudut) sumbu roda terhadap sumbu robot, $\beta$ adalah posisi (sudut) setir terhadap sumbu roda, $l$ adalah jarak antara pusat (origin) robot dengan pusat (origin) roda, $r$ adalah jari-jari roda, dan $\dot{\varphi}$ adalah kecepatan sudut roda. 


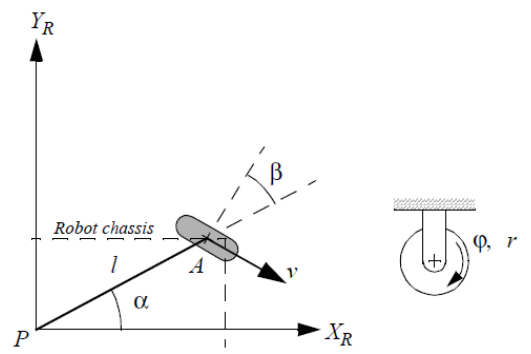

Gambar 3 Roda standar tetap dan parameternya (Siegwart dan Nourbakhsh 2004)

Dari persamaan (5) dan (6) dapat diturunkan kinematika (forward kinematics) untuk robot beroda differential drive seperti yang ditunjukkan pada persamaan (7):

$$
\dot{\xi}_{\mathrm{I}}=\mathrm{R}(\theta)^{-1}\left[\begin{array}{ccc}
\sin (\alpha+\beta) & -\cos (\alpha+\beta) & (-1) \cos \beta \\
\cos (\alpha+\beta) & \sin (\alpha+\beta) & 1 \sin \beta
\end{array}\right]^{-1}\left[\begin{array}{c}
r \dot{\varphi} \\
0
\end{array}\right]
$$

dengan $R(\theta)^{-1}$ adalah inverse dari matriks rotasi, $r \dot{\varphi}_{1}$ adalah kecepatan translasi roda kanan, dan $r \dot{\varphi}_{2}$ adalah kecepatan translasi roda kiri.

Persamaan (7) digunakan untuk mendapatkan kecepatan robot pada koordinat global dengan mengetahui kecepatan roda. Sebaliknya, kecepatan masing-masing roda dari kecepatan robot pada koordinat global dapat diperoleh dengan menggunakan persamaan inverse kinematics. Oleh karena itu, penelitian ini berkontribusi untuk menurunkan persamaan inverse kinematics untuk robot beroda differential drive yang berperan penting dalam pengendalian robot beroda tersebut.

\section{Parallax Robot Shield with Arduino}

Parallax Robot Shield with Arduino adalah robot beroda yang dapat diprogram menggunakan teknologi Arduino. Robot ini memiliki 2 roda standar tetap bermotor di bagian depan dan 1 roda bantu di bagian belakang. Kedua roda bermotor ini berguna untuk memberikan gaya dorong ke depan atau ke belakang. Perbedaan kecepatan kedua roda menciptakan torsi angular yang dimanfaatkan untuk berbelok (Ahmad et al. 2014).

Motor yang digunakan pada robot beroda ini berjenis continous rotation servo yang dikendalikan dengan sinyal pulse width modulation (PWM). Hubungan lebar pulsa PWM dengan kecepatan dan arah rotasi motor servo ditunjukkan pada Gambar 4. Sumbu horizontal grafik menunjukkan lebar pulsa dalam mikrodetik $(\mu \mathrm{s})$, dan sumbu vertikal menunjukkan respons servo dalam rotasi per menit (RPM). Untuk motor servo sebelah kanan, rotasi searah jarum jam ditunjukkan dengan nilai negatif, sedangkan arah berlawanan jarum jam ditunjukkan dengan nilai positif. Grafik servo (kurva transfer) ini berkisar dari sekitar -48 RPM hingga +48 RPM atau pada rentang lebar pulsa dari $1300 \mu$ s hingga $1700 \mu$ s. Motor servo berhenti berputar pada lebar pulsa $1500 \mu$ s. Ketika diberi pulsa PWM sebesar $1300 \mu$ s, motor servo sebelah kanan berputar searah jarum jam dengan kecepatan maksimum. Begitu juga untuk putaran berlawanan arah jarum jam pada lebar pulsa $1700 \mu$ s. Hal sebaliknya berlaku untuk motor servo sebelah kiri.

Kecepatan tidak banyak berubah pada lebar pulsa $1300 \mu$ s sampai $1400 \mu$ s dan pada lebar pulsa $1600 \mu$ s sampai $1700 \mu$ s. Sedangkan, pada lebar pulsa $1400 \mu$ s hingga $1600 \mu$ s, kontrol kecepatan berbentuk hampir linear. Dalam rentang ini, perubahan dalam lebar pulsa akan menghasilkan perubahan kecepatan yang sesuai. Oleh karena itu, lebar pulsa disarankan berada pada rentang $1400 \mu$ s hingga $1600 \mu \mathrm{s}$. Penelitian Abiyoga (2018) telah menggunakan robot beroda ini yang telah dilengkapi dengan GPS + sensor kompas (Gambar 5). 


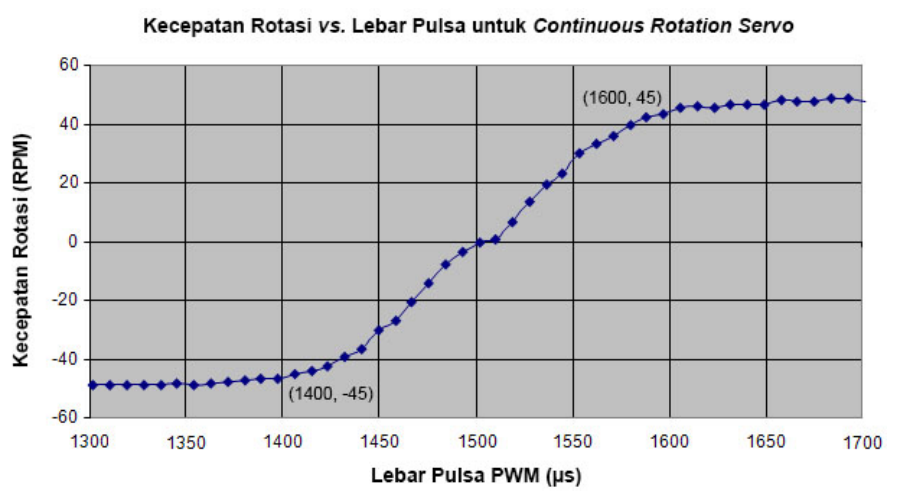

Gambar 4 Hubungan pulsa PWM dengan kecepatan servo (Lindsay 2016).

\section{U-blox NEO-6M GPS Integrated with Honeywell Compass HMC5883L}

U-blox NEO-6M GPS integrated with Honeywell compass HMC5883L (Gambar 6) adalah perangkat GPS yang terintegrasi sensor kompas. GPS merupakan sistem penentuan letak suatu objek di permukaan bumi dengan bantuan penyelarasan sinyal satelit. Setidaknya 4 satelit harus terhubung dengan suatu penerima di permukaan bumi agar dapat menentukan perkiraan koordinat posisi suatu objek (Hofmann-Wellenhof et al. 2012). Sementara itu, kompas yang terintegrasi dengan GPS ini berfungsi untuk mengetahui arah gerak suatu objek.

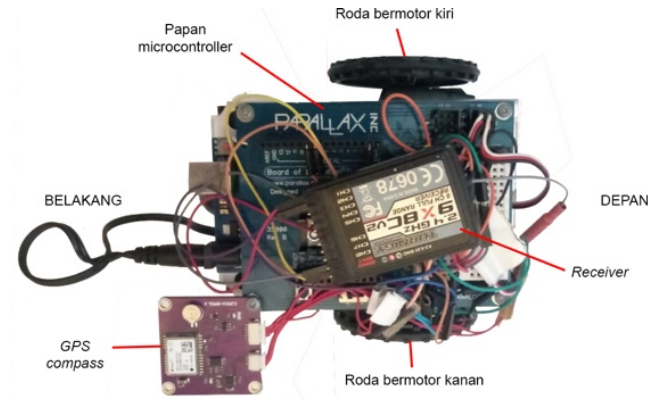

Gambar 11 Robot beroda yang digunakan.

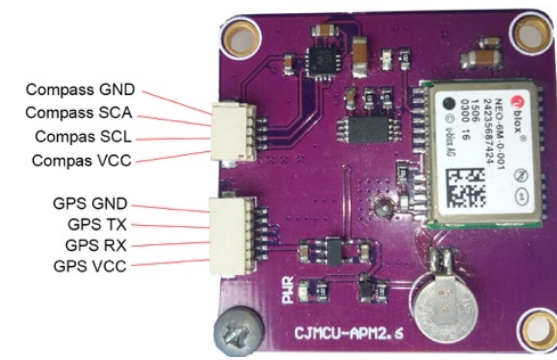

Gambar 12 U-blox NEO-6M GPS integrated with Honeywell compass HMC5883L.

\section{Tahapan Penelitian}

Diagram alir tahapan penelitian ini ditunjukkan pada Gambar 7. Penjelasan masingmasing tahapan adalah sebagai berikut:

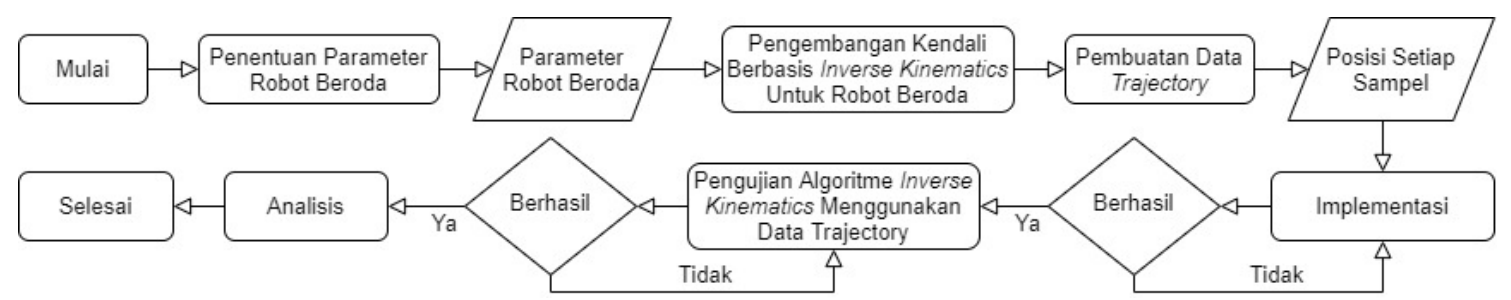

Gambar 7 Diagram alir tahapan penelitian.

\section{Penentuan Parameter Robot Beroda}

Tahapan ini dilakukan dengan cara mengukur parameter nyata dari robot beroda yang digunakan. Pada penelitian ini, nilai $\beta$ untuk masing-masing roda pada robot tetap, karena robot yang digunakan tidak memiliki setir. Parameter robot dan ilustrasinya ditunjukkan pada Gambar 8, dengan penjelasan sebagai berikut:

1 jari-jari roda $(r): 3.3 \mathrm{~cm}$,

2 jarak antara pusat (origin) robot dengan pusat (origin) roda $(l): 5.35 \mathrm{~cm}$,

3 posisi (sudut) sumbu roda terhadap sumbu robot $(\alpha): \alpha_{1}=-90^{\circ}, \alpha_{2}=90^{\circ}$,

4 posisi (sudut) setir terhadap sumbu roda $(\beta): \beta_{1}=180^{\circ}, \beta_{2}=0^{\circ}$. 


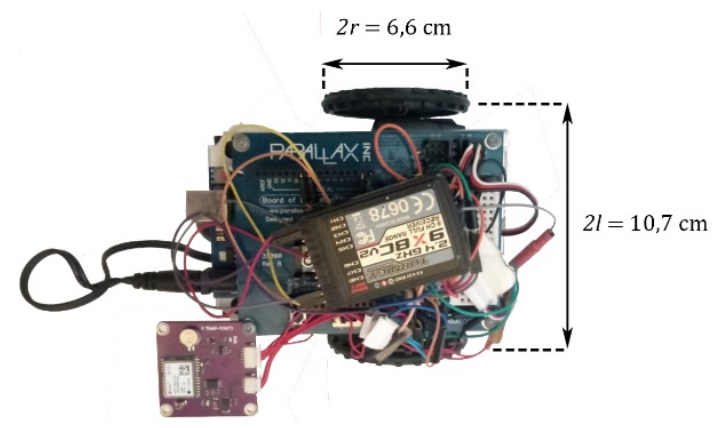

a) Dimensi fisik robot

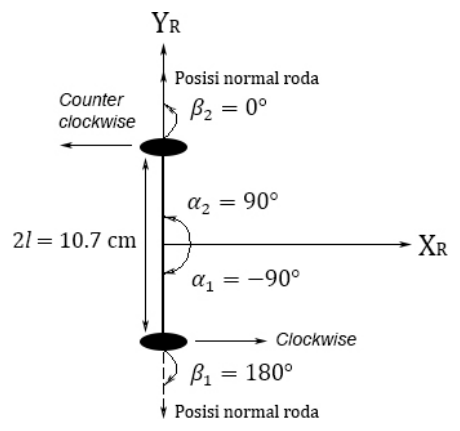

b) Dimensi sudut posisi roda

Gambar 13 Parameter robot beroda.

\section{Pengembangan Kendali Berbasis Inverse Kinematics Untuk Robot Beroda}

Nilai-nilai parameter robot yang telah diukur kemudian digunakan untuk menggantikan variabel pada persamaan (5) dan (6) sehingga dihasilkan persamaan (8).

$$
\left[\begin{array}{ccc}
\sin \left(-90^{\circ}+180^{\circ}\right) & -\cos \left(-90^{\circ}+180^{\circ}\right) & (-l) \cos 180^{\circ} \\
\sin \left(90^{\circ}+0^{\circ}\right) & -\cos \left(90^{\circ}+0^{\circ}\right) & (-l) \cos 0^{\circ} \\
\cos \left(-90^{\circ}+180^{\circ}\right) & \sin \left(-90^{\circ}+180^{\circ}\right) & l \sin 180^{\circ} \\
\cos \left(90^{\circ}+0^{\circ}\right) & \sin \left(90^{\circ}+0^{\circ}\right) & l \sin 0^{\circ}
\end{array}\right] \mathrm{R}(\theta) \dot{\xi_{\mathrm{I}}}=\left[\begin{array}{c}
\mathrm{r} \dot{\varphi_{1}} \\
\mathrm{r} \dot{\varphi_{2}} \\
0 \\
0
\end{array}\right] .
$$

Berdasarkan persamaan (9) dan rumus kinematika untuk robot beroda differential drive pada persamaan (7), persamaan inverse kinematics untuk robot beroda dapat diturunkan seperti pada persamaan (10).

$$
\begin{gathered}
{\left[\begin{array}{ccc}
1 & 0 & 1 \\
1 & 0 & -1 \\
0 & 1 & 0 \\
0 & 1 & 0
\end{array}\right] \mathrm{R}(\theta) \dot{\xi}_{I}=\left[\begin{array}{c}
r \dot{\varphi}_{1} \\
r \dot{\varphi}_{2} \\
0 \\
0
\end{array}\right] .} \\
\dot{\varphi}_{\dot{\varphi}_{2}}=\left[\begin{array}{ll}
r & 0 \\
0 & r
\end{array}\right]^{-1}\left[\begin{array}{ccc}
1 & 0 & 1 \\
1 & 0 & -1
\end{array}\right]\left[\begin{array}{ccc}
\cos (\theta) & \sin (\theta) & 0 \\
-\sin (\theta) & \cos (\theta) & 0 \\
0 & 0 & 1
\end{array}\right]\left[\begin{array}{c}
\dot{x} \\
\dot{y} \\
\dot{\theta}
\end{array}\right],
\end{gathered}
$$

dengan $r=3.3 \mathrm{~cm}$ dan $l=5.35 \mathrm{~cm}$.

Hasil yang didapat dari persamaan (10) berupa kecepatan sudut roda kanan $\left(\dot{\varphi_{1}}\right)$ dan roda kiri $\left(\dot{\varphi}_{2}\right)$ dalam satuan radian per detik $(\mathrm{rad} / \mathrm{s})$. Hasil tersebut kemudian diubah menjadi kecepatan rotasi $\left(\omega_{c y c}\right)$ dengan satuan rotasi per menit (RPM) menggunakan persamaan (11):

$$
\omega_{c y c}(\mathrm{RPM})=\frac{\dot{\varphi}(\mathrm{rad} / \mathrm{s})}{2 \pi} \times 60 .
$$

Setelah itu, kecepatan rotasi dikonversi kembali menjadi sinyal PWM menggunakan persamaan garis lurus dengan memperhatikan kecepatan motor yang digunakan pada Gambar 4 dengan mengasumsikan persamaan garis untuk $1400 \mu$ s hingga $1600 \mu$ s adalah linear dan ilustrasinya dapat dilihat pada Gambar 9 (Lindsay 2016, dengan modifikasi). 


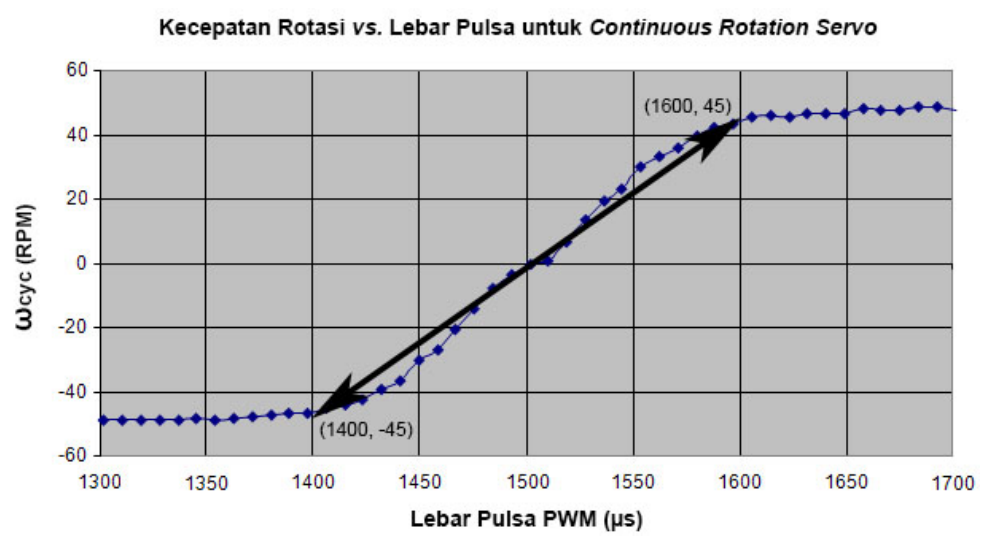

Gambar 14 Bentuk linear kecepatan motor.

Untuk memperoleh nilai pulsa dengan kecepatan yang sesuai, digunakan persamaan garis lurus yang diturunkan dari dua titik $\left(x_{1}, y_{1}\right)$ dan $\left(x_{2}, y_{2}\right)$ seperti persamaan (12):

$$
\frac{y-y_{1}}{y_{2}-y_{1}}=\frac{x-x_{1}}{x_{2}-x_{1}}
$$

Dari Gambar 9, maka $\left(\mathrm{x}_{1}, \mathrm{y}_{1}\right)=(1400,-45)$ dan $\left(x_{2}, y_{2}\right)=(1600,45)$. Dengan melakukan substitusi pada persamaan (12) diperoleh persamaan (13):

$$
x=\frac{y+675}{0.45}
$$

dengan $x$ adalah parameter pulsa PWM dalam $\mu$ s, dan $y$ adalah kecepatan rotasi motor dalam RPM. Kemudian dari persamaan (13) dapat diturunkan persamaan (14) dan (15):

$$
\begin{aligned}
& P W M_{1}=\frac{\left(675-\omega_{c y c}\right)}{0.45}, \\
& P W M_{2}=\frac{\left(\omega_{c y c}+675\right)}{0.45},
\end{aligned}
$$

dengan $P W M_{1}$ adalah sinyal kendali untuk roda kanan yang berputar searah jarum jam dan $P W M_{2}$ adalah sinyal kendali roda kiri yang berputar berlawanan arah jarum jam.

\section{Pembuatan Data Trajectory}

Langkah ini dilakukan dengan cara membuat data trajectory untuk menentukan arah gerak robot beroda. Trajectory yang dibangkitkan pada penelitian ini (Gambar 10) adalah trajectory garis lurus yang disesuaikan dengan kecepatan maksimum robot, dengan rincian sebagai berikut:

1 jumlah titik sampel: 10 ,

2 jarak tempuh setiap sampel: 0.71 meter pada sumbu $x(\Delta x)$ dan 0.71 meter pada sumbu $y$ $(\Delta y)$

3 orientasi robot pada setiap sampel $(\theta): 45^{\circ}$,

4 sampling time $(t)$ : 7 detik.

Dari data trajectory tersebut, maka didapatkan kecepatan pada persamaan (16):

$$
v=\sqrt{\frac{\Delta x^{2}+\Delta y^{2}}{t}}=\sqrt{\frac{0.71^{2}+0.71^{2}}{7}}=0.143 \mathrm{~m} / \mathrm{s} .
$$


Nilai tersebut lebih rendah daripada kecepatan maksimum robot yaitu $0.172 \mathrm{~m} / \mathrm{s}$, artinya trajectory tersebut feasible untuk diterapkan. Berdasarkan trajectory tersebut, maka nilai-nilai $\dot{x}, \dot{y}$, dan $\dot{\theta}$ yang dimasukkan ke persamaan (10) adalah sebagai berikut:

$1 \quad \dot{x}=\frac{\Delta x}{t}=\frac{0.71}{7}=0.101 \mathrm{~m} / \mathrm{s}$,

$2 \dot{y}=\frac{\Delta y}{t}=\frac{0.71}{7}=0.101 \mathrm{~m} / \mathrm{s}$,

$3 \dot{\theta}=0 \mathrm{rad} / \mathrm{s}$, karena $\theta$ pada setiap sampel tetap.

\section{Implementasi}

Tahapan ini dilakukan dengan cara menanamkan program kendali algoritme inverse kinematics untuk robot beroda ke mikrokontroler yang terpasang pada robot.

\section{Pengujian Algoritme Inverse Kinematics menggunakan Data Trajectory}

Pada tahap ini, program kendali dengan algoritme inverse kinematics yang telah dibuat ditanamkan pada robot beroda menggunakan Arduino. Program kendali ini diujikan untuk trajectory garis lurus yang ditunjukkan pada Gambar 10. Dengan demikian, robot beroda yang digunakan dapat berjalan secara otonom. Pengujian ini dilakukan sebanyak 15 kali di lapangan terbuka, yaitu 8 kali (pengujian 1-8) pada saat cuaca cerah dan 7 kali (pengujian 9-15) pada saat cuaca mendung. Untuk mengetahui pergerakan robot yang diujikan, posisi robot direkam dengan menggunakan tiga metode, yaitu (1) observasi di lapangan secara manual menggunakan meteran, (2) observasi menggunakan perangkat GPS yang terpasang pada robot, dan (3) observasi menggunakan GPS smartphone. Pada awalnya, posisi robot direkam hanya menggunakan GPS robot. Namun, karena galat yang dihasilkan dari perangkat tersebut cukup besar, GPS smartphone juga digunakan. Setelah dilakukan percobaan, ternyata GPS smartphone juga menghasilkan galat yang besar. Oleh karena itu, dilakukan pula pengukuran secara manual dengan cara mengukur posisi robot pada sumbu $x$ dan $y$ global menggunakan meteran pada setiap sampelnya $\left(X_{G}, Y_{G}\right)$.

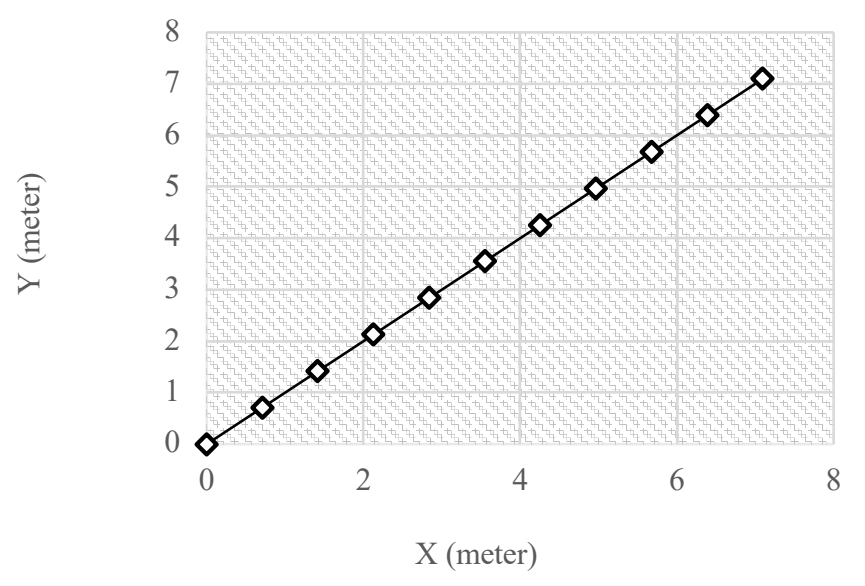

Gambar 15 Trajectory garis lurus

\section{Analisis}

Analisis dilakukan terhadap hasil pengujian yang mencakup perhitungan akurasi seberapa tepat robot bergerak mengikuti trajectory garis lurus yang ditunjukkan pada Gambar 10. Oleh karena itu, harus diketahui terlebih dahulu perubahan jarak robot dari titik awal dengan melakukan konversi pada data posisi robot yang telah didapatkan dari perangkat GPS robot, dan GPS smartphone. Data longitude dan latitude dari GPS ini diolah menjadi data posisi dengan menggunakan konvensi east north up (ENU), yaitu arah sumbu East yang bersesuaian dengan pertambahan posisi longitude adalah arah sumbu $x$ positif, arah sumbu North yang 
bersesuaian dengan pertambahan posisi latitude adalah sumbu $y$ positif, dan arah ke atas (Up) adalah sumbu $z$ positif (Priandana 2017). Posisi robot pada sumbu $x$ dan $y$ global diperoleh dengan asumsi bahwa posisi awal robot $\left(x_{R}(0), y_{R}(0)\right)$ adalah pada koordinat $(0,0)$, dengan persamaan (17) dan (18):

$$
\begin{gathered}
x_{R}(k)=(\text { longitude }(k)-\text { longitude }(0)) \times 111000, \\
y_{R}(k)=(\operatorname{latitude}(k)-\text { latitude }(0)) \times 111000,
\end{gathered}
$$

dengan $\boldsymbol{k}$ adalah indeks untuk sampel data yang diambil. Dengan persamaan tersebut akan diketahui perubahan jarak robot dari posisi awal dalam meter.

Metode yang digunakan untuk menghitung akurasi hasil pengujian yaitu mean squared error (MSE) yang dapat dianalogikan sebagai varian ditambah dengan kuadrat bias dari suatu model. Persamaan dari metode MSE ditunjukkan pada persamaan (19):

$$
M S E=\frac{1}{n} \sum_{i=1}^{n}\left(Y_{i}-\widehat{Y}_{l}\right)^{2},
$$

Dengan $Y_{i}=$ data trajectory pada sampel ke- $i, \hat{Y}_{i}=$ data hasil pengujian sebenarnya pada sampel ke- $i$, dan $n=$ banyaknya sampel data. Kinerja kendali semakin baik jika nilai MSE yang dihasilkan semakin mendekati nol.

\section{HASIL DAN PEMBAHASAN}

Kinerja kendali berdasarkan nilai MSE-nya ditunjukkan pada Tabel 1 dan perbandingannya ditunjukkan pada Gambar 11. Pada Tabel 1, pengujian 1-8 dilakukan pada saat cuaca cerah dan pengujian 9-15 dilakukan pada saat cuaca mendung. Nilai MSE menunjukkan galat antara posisi yang ditetapkan oleh trajectory pada Gambar 10 dengan posisi robot yang terukur, baik dari pengukuran berdasarkan observasi manual, perangkat GPS robot, maupun GPS smartphone. Hasil pergerakan robot dalam satuan meter pada setiap sampelnya dapat dilihat pada Gambar 12-14.

Berdasarkan hasil tersebut, terlihat bahwa error yang didapatkan dari pengukuran manual di lapangan lebih rendah dibandingkan dengan error yang didapatkan dari perangkat GPS. Selain itu, terlihat juga bahwa robot pada awalnya bergerak lurus mengikuti trajectory, namun pada akhirnya bergerak sedikit berbelok. Hal ini dapat terjadi karena adanya gesekan antara roda robot dengan kondisi tanah yang tidak rata sehingga gerakan robot menjadi sedikit berbelok. Sementara itu, untuk hasil yang diperoleh dari perangkat GPS, baik GPS robot maupun GPS smartphone, terlihat bahwa galat yang didapatkan pada cuaca cerah cukup rendah dibandingkan dengan galat pada cuaca mendung. Dengan demikian, dapat disimpulkan bahwa perangkat GPS sangat sensitif dengan cuaca. Perbedaan posisi yang terekam oleh kedua perangkat GPS ini mungkin disebabkan oleh perbedaan jenis GPS yang digunakan.

Berdasarkan pengujian yang telah dilakukan, hasil terbaik yang didapatkan yaitu pada pengujian ke-7, yaitu ketika pergerakan robot yang diperoleh dari pengukuran berdasarkan observasi di lapangan menghasilkan nilai galat relatif rendah, yaitu 0.2 meter dibandin observasi lainnya. Hasil terbaik juga diperoleh dari pengukuran berdasarkan observasi di lapangan dengan rata-rata nilai galat cukup rendah, yaitu 0.9 meter. Sementara itu, untuk hasil dari perangkat GPS, ternyata GPS robot lebih baik dibandingkan GPS smartphone dengan ratarata nilai galat yaitu 15.0 meter untuk GPS robot, dan 47.0 meter untuk GPS smartphone. 
Tabel 2 MSE posisi robot

\begin{tabular}{|c|c|c|c|c|c|c|c|c|c|}
\hline \multirow{2}{*}{ Pengujian } & \multicolumn{3}{|c|}{ MSE Posisi pada Sumbu-X } & \multicolumn{3}{|c|}{ MSE Posisi pada Sumbu-Y } & \multicolumn{3}{|c|}{ MSE } \\
\hline & A & B & $\mathrm{C}$ & A & B & $\mathrm{C}$ & $\mathrm{A}$ & B & $\mathrm{C}$ \\
\hline 1 & 2.0 & 10.1 & 7.0 & 1.9 & 3.7 & 6.3 & 2.0 & 6.9 & 6.6 \\
\hline 2 & 1.4 & 10.3 & 4.4 & 2.9 & 21.1 & 7.8 & 2.2 & 15.7 & 6.1 \\
\hline 3 & 1.1 & 1.9 & 3.3 & 1.5 & 8.2 & 2.8 & 1.3 & 5.0 & 3.0 \\
\hline 4 & 1.1 & 2.5 & 2.5 & 1.0 & 5.2 & 1.1 & 1.0 & 3.9 & 1.8 \\
\hline 5 & 1.1 & 0.4 & 3.5 & 0.6 & 1.0 & 5.6 & 0.8 & 0.7 & 4.6 \\
\hline 6 & 0.5 & 2.4 & 15.8 & 0.4 & 1.3 & 28.1 & 0.4 & 1.8 & 21.9 \\
\hline 7 & 0.3 & 21.7 & 21.8 & 0.1 & 11.3 & 18.5 & 0.2 & 16.5 & 20.1 \\
\hline 8 & 1.3 & 1.9 & 20.3 & 2.0 & 15.8 & 22.1 & 1.7 & 8.8 & 21.2 \\
\hline 9 & 1.0 & 4.8 & 62.6 & 1.9 & 3.2 & 45.5 & 1.5 & 4.0 & 54.0 \\
\hline 10 & 0.8 & 2.6 & 12.0 & 0.4 & 10.8 & 205.3 & 0.6 & 6.7 & 108.6 \\
\hline 11 & 0.2 & 2.8 & 47.1 & 0.3 & 0.4 & 39.0 & 0.3 & 1.6 & 43.0 \\
\hline 12 & 0.2 & 11.9 & 49.1 & 0.3 & 5.0 & 167.6 & 0.3 & 8.5 & 108.3 \\
\hline 13 & 0.1 & 1.9 & 82.9 & 0.3 & 5.5 & 18.5 & 0.2 & 3.7 & 50.7 \\
\hline 14 & 0.1 & 5.1 & 52.5 & 0.3 & 237.1 & 32.0 & 0.2 & 121.1 & 42.2 \\
\hline 15 & 0.2 & 38.0 & 364.8 & 0.3 & 2.7 & 60.7 & 0.2 & 20.4 & 212.8 \\
\hline Rata-rata & 0.8 & 7.9 & 50.0 & 0.9 & 22.1 & 44.1 & 0.9 & 15.0 & 47.0 \\
\hline Standar deviasi & 0.5 & 10.0 & 90.6 & 0.8 & 59.73 & 60.6 & 0.6 & 29.9 & 57.4 \\
\hline
\end{tabular}

${ }^{\mathrm{a}} \mathrm{A}$ adalah hasil yang diperoleh berdasarkan observasi di lapangan, B adalah hasil yang diperoleh dari GPS robot, $\mathrm{C}$ adalah hasil yang diperoleh dari GPS smartphone.

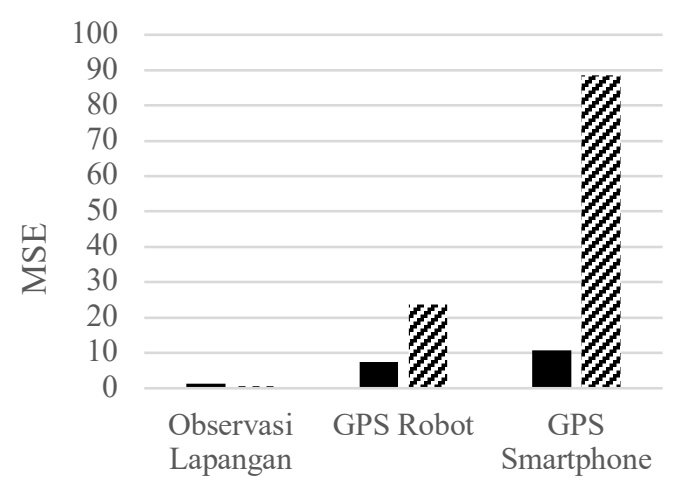

Metode Perekaman Posisi Robot

- Cuaca Cerah $\boldsymbol{z}$ Cuaca Mendung

Gambar 16 Perbandingan MSE

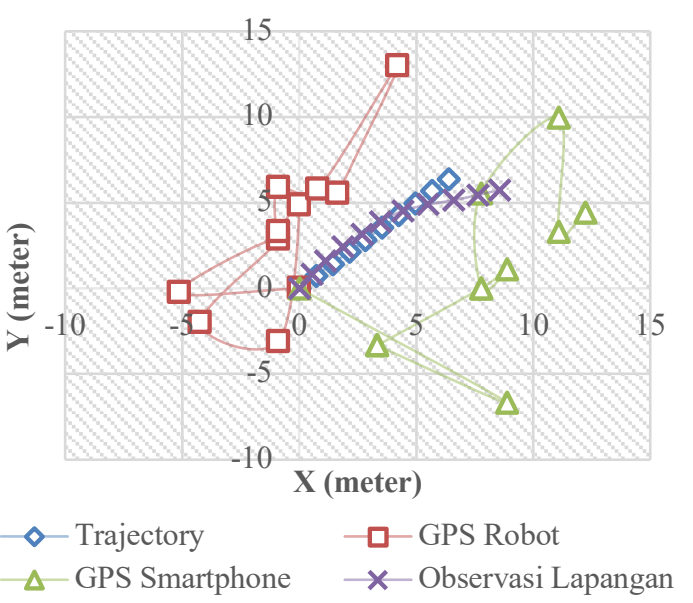

Gambar 18 Contoh hasil pengujian ke-7 menggunakan data trajectory garis lurus.

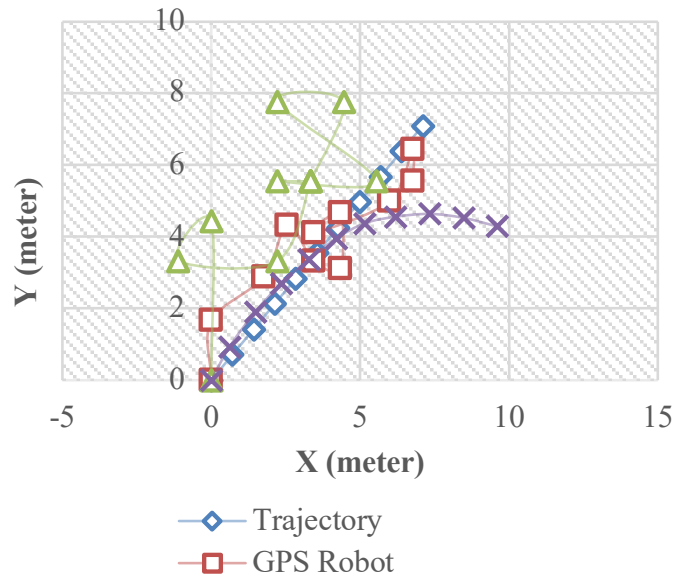

Gambar 17 Contoh hasil pengujian ke-5 menggunakan data trajectory garis lurus

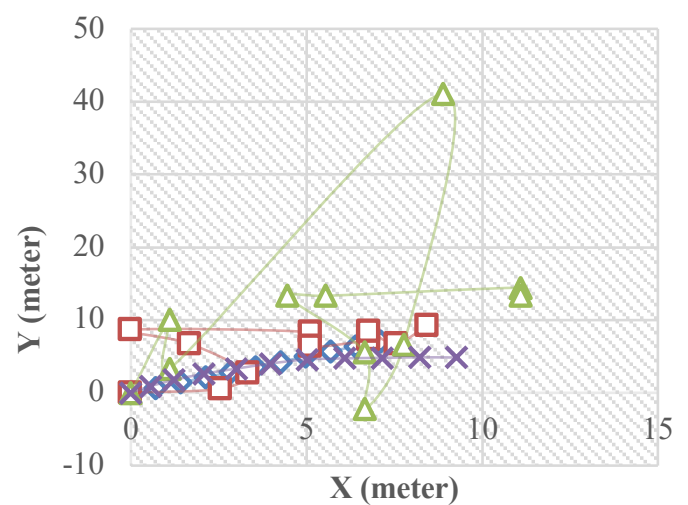

$\begin{array}{ll}- \text { Trajectory } & \square \text {-GPS Robot } \\ -\Delta \text { GPS Smartphone } \quad x \text { Observasi Lapangan }\end{array}$

Gambar 19 Contoh hasil pengujian ke-10 menggunakan data trajectory garis lurus. 


\section{SIMPULAN}

Penelitian mengenai kendali robot beroda otonom dengan inverse kinematics ini dikerjakan menggunakan metode yang terdiri atas enam tahapan, yaitu penentuan parameter robot beroda, pengembangan kendali berbasis inverse kinematics untuk robot beroda, pembuatan data trajectory, implementasi, pengujian algoritme inverse kinematics menggunakan data trajectory, dan analisis. Setelah sistem kendali ini dibuat dan diterapkan pada robot beroda, pengujian dilakukan menggunakan trajectory garis lurus yang kemudian direkam data pergerakannya dari pengukuran berdasarkan observasi di lapangan, GPS yang terpasang pada robot, dan GPS smartphone. Hasil pengujian menunjukkan bahwa robot beroda dapat berjalan mengikuti trajectory dengan rata-rata nilai galat yaitu 0.9 meter untuk pengukuran berdasarkan observasi di lapangan, 15.0 meter untuk GPS robot, dan 47.0 meter untuk GPS smartphone. Dengan demikian, dapat disimpulkan bahwa robot beroda yang digunakan dapat dikendalikan dengan inverse kinematics pada trajectory yang diujikan dengan galat relatif rendah berdasarkan hasil yang diperoleh dari pengukuran sesuai observasi di lapangan.

\section{SARAN}

Penelitian ini dapat diperbaiki atau dikembangkan dengan cara menggunakan teknik lokalisasi robot selain GPS agar diperoleh data posisi robot yang lebih akurat pada saat melakukan pengujian.

\section{DAFTAR PUSTAKA}

Abiyoga Iqbal. 2018. Pengembangan sistem kendali berbasis kecerdasan komputasional dengan metode backpropagation neural network untuk robot beroda [skripsi]. Bogor (ID): Institut Pertanian Bogor

Ahmad Omar, Ullah Irfan, Iqbal Jamshed. 2014. A multi-robot educational and research network. International Journal of Academic Research. 6(2):217-222.doi:10.7813/20754124.2014/6-2/ A.32

Almurib HAF, Isa AAM, Al-Assadi HMAA. 2011. Direct neural network control via inverse modelling: Application on induction motors. Artificial Neural Networks - Industrial and Control Engineering Applications. doi:10.5772/16052.

Gu J, Ma X, Liu F, Wang Y, Ren H. 2017. Mathematical modeling and intelligent algorithm for multi-robot path planning. Mathematical Problems in Engineering. doi:10.1155/2017/ 1465158.

Hofmann-Wellenhof B, Lichtenegger H, Collins J. 2001. Global positioning system: theory and practice. Ed ke-5. New York (US): Springer-Verlag Wien.

Kusumoputro B, Suprijono H, Heryanto MA, Suprapto BY. 2016. Development of an attitude control system of a heavy-lift hexacopter using Elman recurrent neural networks. 2016 22nd International Conference on Automation and Computing (ICAC). Colchester (UK): IEEE.

Laumond JP, Sekhavat S, Lamiraux F. 1998. Guidelines in nonholonomic motion planning for mobile robots. Di dalam: Robot Motion Planning and Control, Laumond JP, editor. Volume ke-229. Lecture Notes in Control and Information Sciences. London (GB): Springer-Verlag Berlin Heidelberg. hlm 1-53.

Lindsay Andy. 2016. Robotics with the BOE Shield-bot for Arduino. Versi ke-1.1. California (US): Parallax Inc. 
Liu Y, Nejat G. 2013. Robotic urban search and rescue: A survei from the control perspective. Journal of Intelligent and Robotic Systems. 72(2):147-165.doi:10.1007/s10846-0139822-x.

Maulana E, Muslim MA, Zainuri A. Inverse kinematics of a two-wheeled differential drive an autonomous mobile robot. 2014 Electrical Power, Electronics, Communications, Controls, and Informatics Seminar (EECCIS). Malang (ID): IEEE.

Naveed K, Khan ZH. 2017. Adaptive path tracking control design for a wheeled mobile robot. 2017 3rd IEEE International Conference on Control Science and Systems Engineering (ICCSSE). Beijing (CN): IEEE.

Priandana K. 2017. Sistem kendali kapal-pengejar-nirawak berbasis neural networks menggunakan ensemble kalman filter sebagai prediktor informasi radar [disertasi]. Depok (ID): Universitas Indonesia.

Priandana K, Buono A, Wulandari. 2017. Hexapod leg coordination using simple geometrical tripod-gait and inverse kinematics approach. 2017 International Conference on Advanced Computer Science and Information Systems (ICACSIS). Bali (ID): IEEE.

Siegwart R, Nourbakhsh IR. 2004. Introduction to autonomous mobile robots. London (GB). MIT Press.

Thao NGM, Nghia DH, Phuc NH. 2010. A PID back-stepping controller for two-wheeled selfbalancing robot. International Forum on Strategic Technology 2010. Ulsan (KR): IEEE. 